\title{
Military Take Over by General Ershad and Constitutional Amendment in Bangladesh: A Modest Politico-legal Study
}

\author{
Dr. Md. Morshedul Islam, Professor \\ Department of Law, University of Rajshahi, Bangladesh
}

\begin{abstract}
General H.M.Ershad grabbed state power by military coup. He prolonged his reign by introducing self style democracy. In doing so he tried his best to create a better image by resorting to different people oriented activities. But his political ambition faced huge challenge from the opposition. The regime succeeded to manipulate opposition movement and persuade all political parties except BNP to take part in third parliamentary polls and thus managed to gain constitutional sanction of his reign. But the regime did never get any approval and sympathy from BNP led by Khaleda Zia. This article is intended to show the process of confidence building of the regime, how political motives were injected through its programs, how did it manipulate opposition movement and attain recognition of its actions.
\end{abstract}

Keywords: Martial law, Democratic Rule, Opposition Movement, Dialogue, Election, Neutral Government, Political Alliance.

DOI: $10.7176 / \mathrm{JLPG} / 99-04$

Publication date:July $31^{\text {st }} 2020$

1. Introduction: That the spirit of liberation war i.e., exploitation free democratic society based on equality and justice denied during the first civilian government under the father of the nation Sheikh Mujibur Rahman was felt under the reign of Ziaur Rahman in Bangladesh. The exploration of this spirit of liberation war was fumbled by the sudden assassination of President Ziaur Rahman on May 30, 1981. With the emergence of General H. M. Ershad in the saddle of power the short journey of infant democracy halted in Bangladesh on March 24, 1982. In spite of taking state power by bloodless coup, military government of H.M. Ershad did a lot for the up-lift of common people in order to make his place in their hearts. Pro-people activities of the military regime received appreciation in civil society as well as rural people but enchained democratic atmosphere blurred that achievement. The movement for the restoration of democratic rule led by Begum Khaleda Zia, widow of President Zia and chairperson of BNP, created stiff and die-hard opposition for the regime. Though the regime succeeded to broker a deal with other opposition parties- Awami League(Hasina) and Jamaat, and thus managed to create elected Parliament and President for the sanction of his illegal rule yet charismatic and uncompromising leadership of Khaleda Zia alone, undoubtedly kept the rule of military junta uncertain and vulnerable throughout his reign.

1.1 Military take over: Military take over is not unusual in underdeveloped and developing countries. Lack of experience as well as efficiency in running post colonial administration, ignorance of democratic norms and values by political leadership, exorbitant corruption and lawlessness pave the way for military takeover. Bangladesh is no exception to that. Immediately after the brutal assassination of elected President Ziaur Rahman on May 30, 1981, corruption in government and lawlessness across the country surfaced in such a way that the then political government leant towards the army for its survival. Observing the weakness of the political government Army Chief of Staff H.M. Ershad injected some of its ideas into top guns of the government as well as leader based political parties. Consequently in the pressure of Army Chief of Staff Lt. General H.M. Ershad and leaders of small political parties, government formed 11-member National Security Council (NSC) with Chief of Army, Navy and Air forces in order to ensure the participation of armed forces in socio-economic development of the country on January 1, 1982. Lt. Gen. H.M. Ershad took over state power by sword by ousting democratically elected President Justice Abdus Sattar on March 24, 1982 with a view to realize the duties assigned to NSC. ${ }^{1}$

Though military takeover by H.M. Ershad was illegal yet his action was appreciated by ousted President Justice Abdus Sattar in a nationwide radio speech on March 25, 1982. ${ }^{2}$ It was not clear why ousted President Abdus Sattar supported military takeover by CMLA Ershad. He might have been forced to do that by the military government. However, in order to legalise his taking over of state power General H.M.Ershad played different cards and took some extraordinary people oriented programmes within his first four years in office.

The Bangladesh Observer, March 25, 1982

Ibid, March 26, 1982 


\subsection{Cleanliness}

Cleanliness is a part of Iman. It reflects the honesty and sincerity of the people, society as well as nation. Ershad emphasized on the decency and cleanliness. He directed every individual, institution and body as well as private individual to keep their possessions, office, administration, building, structure, road and passage, neat and clean. ${ }^{1}$ As a part of that drive CMLA HM Ershad had made a sudden visit to the premises of Secretariat on April 5, 1982. ${ }^{2}$ However later on lack of enthusiasm in carrying out this drive was seen in government activities.

\subsection{Drive against Corruption}

On April 14, 1982 Ershad in a Bangla New Year message called upon the nation to declare "Jehad" against accumulated injustice, unlimited corruption and wastage. ${ }^{3}$ On April 3, 1982 he directed Union Parishad Chairmen and Gram Sarkar Prodhans to refund government's money which had not been used for public purpose. ${ }^{4}$ He took step for the trial of corrupt government officials and requested common people to make complaints as well as provide information of corruption and misuse of power by government officers. ${ }^{5}$ Accordingly huge number of political and permanent executives were arrested and tried for corruption, and given different punishments. But this drive had become a farce when it was seen that President Ershad and twelve ministers of his government were arrested on corruption charges on December 12, 1990.

\subsection{Austerity Drive}

Poor economic condition led Army Chief of Staff H.M. Ershad to declare martial law. In order to improve it he perhaps the first head of state since independence issued nationwide austerity drive on April 13, 1982. ${ }^{6}$ And he set up an example of austerity by attending his CMLA office by a bicycle on April 30, 1982.7

\subsection{Permanent Bench of the High Court Division outside Dhaka}

H.M. Ershad set up permanent Benches of the High Court Division of the Supreme Court of Bangladesh at Rangpur, Comilla, Jessore, Barisal, Chittagong and Sylhet. He also established Munsifs Courts and other courts in Thana Head Quarters throughout the country, excluding Chittagong Hill Tracts by phase. He said that government would bring justice to the door of the common people. ${ }^{8}$

This decentralization of judiciary reduced common peoples' sufferings with regard to filing of suits, handling of litigations, expense of cases and time. Though people started getting benefits of decentralization of judiciary yet the lawyers' interest was affected severely. It forced the established lawyers to go to remote areas in search of clients.

\subsection{Desire for Power and 18-Point Programme}

CMLA H.M. Ershad on January 30, 1983 expressed his political ambition and said, "Democracy is our goal and in democracy effective opposition must be ensured." In order to materialize his political desire on March 17, 1983 he declared his 18 -point programme. The programmes were: ${ }^{9}$

1) To reach the fruits of political independence to the people through economic emancipation.

2) Equitable distribution of national wealth by reducing the gap between the rich and the poor.

3) Village oriented development.

4) Proper distribution and competition of industrial products through increased production.

5) Increase of agricultural product and self sufficiency in food.

6) Land reforms ensuring due share for peasants and security of their livelihood.

7) Establishment of Gramin Bank (rural bank). ${ }^{10}$

8) Incentives to private sector industries, investment and creation of investment climate.

9) Cooperatives and cottage industries

10) Reorganization of administration and judiciary, decentralization and austerity.

11) Improvement in educational system to provide security to future career of students.

12) To create maximum possible employment opportunity.

The Bangladesh Observer, April 4, 1982

The Ittefaq, April 6, 1982

Ibid, April 15, 1982

Ibid, April 4, 1982

Ibid, April 11, 1982

Ibid, April 14, 1982

Ibid, May 1, 1982

Ibid, May 10, 1982

Ibid, March 18, 1983

Dr. Mohammad Yunus established this bank under the rural banking project in $1976 .{ }^{10}$ Ershad government gave this the shape of corporate body under the Grameen Bank Ordinance, 1983 for extending credit exclusively to the landless men and women in rural Bangladesh. 
13) To help women establish their rightful place in the society through participation in national development.

14) To provide healthcare facility to all people.

15) Population control.

16) Jehad against corruption.

17) To turn politics into politics of work.

18) Reflection of Islamic values in national life and upholding of own language, culture, tradition and heritage.

For the purpose of materializing this 18-point programme, 18-point Implementation body was formed with Mr. Mahbubur Rahman, Minister for Local Government, Rural Development, Cooperatives and Religious Affairs, as it's Chairman was formed on March 18, 1983. ${ }^{1}$

Natun Bangla Chhatra Samaj (New Bangla Student Society) was formed with Rafiqul Haq Hafiz as Convener and 41-member Central Convening Committee was formed on March 27, 1983. ${ }^{2}$ On April 3, 1983 Natun Bangla Jubo Sanghati (New Bangla Youth Solidarity) with A.T.M Rafiqul Islam as Convener, and Mr. Mian Shahid Hussain and Mr. Anisuzzaman Khakan former MP as Joint Conveners was formed under the shadow of ML regime. This royal organization termed CMLA H.M. Ershad as the worthy successor of Zia. The regime used Zia for political gain.

On August 23, 1983 Mr. Mahmudur Rahman, Local Government Minister, declared that a national conference of the representatives of the 18-point Implementation Council cells would be held on November 7, $1983 .^{3}$ In order to popularize government's 18-point programme it introduced "Grehasree" scheme in the northern districts. Grehasree was related to Medicare and family planning which was one of the programmes of 18-point. ${ }^{4}$

In order to have the support of the lawyers on August 30, 1983 Dhaka Bar 18-point Implementation Committee was formed with Mohammad Momtazuddin, Advocate as President, Mr. Mojibur Rahman, Advocvate as Vice-President. ${ }^{5}$ On September 3, 1983 Mr. Mahbubur Rahman, Chairman of 18-point Implementation Council in a meeting said that 18-point programme had become people's property. ${ }^{6}$ Dhaka City Lawyer 18-point Programme Body was formed on September 6, 1983 with S.M. Abed Ali, M.A. Aziz, Fazlul Hoque, Mr. Shamsul Alam Chowdhury etc as members. ${ }^{7}$

On October 9, 1983 18-point Central Executive Council was formed with CMLA H.M. Ershad as it's Chairman and DCMLA On the same day 18-point Central Working Committee was also constituted with CMLA H.M. Ershad as it's Chairman After being elected as the president of 18-point Central Executive Council and Central Working Committee CMLA H.M. Ershad on October 11, 1983 said that 18-point programme had become the Charter of survival. ${ }^{8}$

\subsection{Political Alliances against the Regime}

While Ershad was advancing with the mission of sowing its political root in the people through forming different pro-government organizations major two political parties- BNP and AL (Hasina) formed political alliances with small political parties. Ousted BNP (Satter) party formed seven-party alliance to forge movement against the ML regime on September 6, 1983. Members of seven-party alliance were (1) BNP (Satter), (2) Jatiya League, (3) Ganatantrik Party, (4) United People's Party, (5) NAP(Nuru), (6) Krishak Sramik Party and (7) Bangladesh Communist Party. But after second dialogue with President Ershad NAP (Nuru), Krishak Sramik Party and Jatiya League broke away from seven-party alliance and merged with regime's party front on January $28,1984 .{ }^{9}$ Thus seven-party alliance became four-party alliance.

AL (Hasina) formed fifteen-party alliance in early 1983. Components of this alliance were (1)Awami League( Hasina), (2) Gono Azadi League, (3) NAP (M), (4) JSD, (5) JSP, (6) NAP (Haroon), (7) Jatiya Ekota Party, (8) Bangladesh Workers Party, (9) Communist Party of Bangladesh, (10) Sramik Krishak Samajbadi Dal, (11) AL (Farid), (12) AL (Mizan), (13) Samvabadi Dal , (14) Saimybadi Dal (Nagen) and (15) Mazdoor Party. After secret dialogue Hasina on March 21, 1986 announced her decision for participation in election under ML. Consequently seven political parties broke away from her alliance reducing fifteen-party alliance into eightparty alliance.

Fifteen-party alliance on September 30, 1983 put five-point demands viz, (1) restoration of democratic

The Bangladesh Observer, March 19, 1983

Ibid, March 28, 1983, the Ittefaq, March 28, 1983

Ibid, August 23, 1983, the Ittefaq, August 23, 1983

Ibid.

Ibid, August 31, 1983, the Amar Desh, August 31, 1983

Ibid, September 4, 1983, the Banglar Bani, September 4, 1983

Ibid, September 7, 1983, the Ittefaq, September 7, 1983

Ibid, October 12, 1983

Ibid, January 29, 1984 
environment, (2) withdrawal of restriction on political activities, (3) Holding of parliamentary election by winter 1983, (4) Release of all political prisoners, and (5) Punishment to those responsible for mid-February 1983 incident at Dhaka University and asked the government for the realization of their demands. ${ }^{1}$ Seven-party alliance put five demands- withdrawal of ML, restoration of fundamental rights, withdrawal of all restrictions on open politics, holding of Parliamentary polls in winter 1983 and release of all detenus and probe into the midFebruary incident at Dhaka University and demanded for their fulfillment. Both these alliances threatened to start movement if their demands were not met. ${ }^{2}$

\subsection{Local government}

In every political setup local government plays significant role. For proper implementation of government's policies and programmes especially development programmes existence of strong local government bodies is a must. Popularity of the government depends upon the performance of local government bodies. With the aim of establishing sound and healthy local government administration CMLA HM Ershad had set up Upazilla Parishad and transformed subdivisions into districts.

\subsubsection{Upazilla Parishad}

In Bangladesh most of the people live in the rural area. It is immaterial to them who are in the government. They just expect good services. H.M. Ershad when took power, Bangladesh Nationalist Party (BNP) and Bangladesh Awami League two most powerful political parties enjoyed popular support in big cities and towns. And their political hold in these areas was very strong. They (urban people) were politically conscious and change in government affected their interest. The regime launched different pro government organisations with a view to creating its political support in the people. These organisations failed to realize regime's goals in urban areas. On the other hand in rural areas service of the government was treated as the standard of popular support. But these areas were underdeveloped in all respects. Rural people had to come to urban areas for administrative, judicial and medical services. For that they had to overcome lot of hurdles. The regime knew better that by only ensuring these services to the people they could make their rule peaceful. Keeping these aim in view CMLA on April 19, 1982 said, "Government people gap must be bridged." He maintained, "Administrative set up shall be in such type that village people could get the benefit of administration. Administration must be rooted in villages."

Accordingly Upazilla Parishad was set up with TNO, Munsif and Magistrate Courts, Thana Health Complex, Thana Education Office on November 7, 1982. ${ }^{4}$ In order to ensure urban facilities telephone and electric service were arranged in Upazilla head quarter. Roads and highways were developed in these areas. The regime had accumulated fund for the construction of the Jamuna Bridge.

\subsubsection{Subdivision}

CMLA H.M Ershad became President on December 11, 1983 in the face of stiff opposition of BNP led sevenparty alliance. ${ }^{5}$ For creating support base in remote and neglected areas of large districts, government split the large districts and promoted subdivisions to districts for equal development as stipulated in the 18-point programme of the regime. Accordingly Netrokona which was a subdivision of Mymensingh, Kishoregong which was a subdivision of Sylhet, Panchagarh, Thakurgaon, Bhola, Jhalkathi, Chandpur, Brahmonbaria were promoted to district with full administrative and judicial set up. Consequently all subdivisions were promoted to full phase districts.

\subsection{Formation of King Party and Opposition movement}

Ershad withdrew Martial Law on November 15, 1983. It was said earlier that Ershad had launched different committees, groups and organizations for accomplishing its political desire in the name of implementing 18point programme. But it failed to accommodate public support. For power consolidation Ershad formed political party "Janadal" with President Justice Ashanuddin as it's chairman on November 27, 1983. ${ }^{6}$ Opposition observed "sit in" programme on November 28, 1983 across the country in protest of formation of Janadal. ${ }^{7}$ This protest became violent which caused four deaths and 299 injuries. Being fearful of more opposition protest Ershad within thirteen days after the start of open politics re-imposed ML banning all sorts of political activities. ${ }^{8}$ Government imposed curfew in big cities. In order to contain the situation Khaleda Zia and Sheikh Hasina were arrested and put into protective custody on November $29,1983 .{ }^{9}$ Under this hot atmosphere Ershad

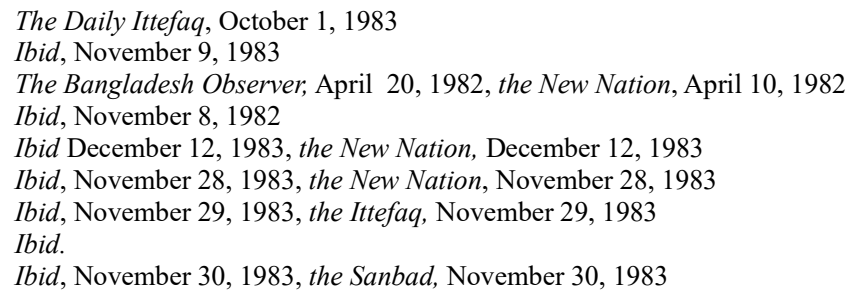


became President on December $11,1983 .^{1}$

In order to gain strength Kings party Janadal and 18-point Implementation Council merged on March 23, 1984 with president Ershad as it's Chairman. ${ }^{2}$ Inspite of forming Jote ML regime could not earn the support of the common people because of the popularity of Khaleda Zia and Hasina. On March 30, 1984 under the shadow of the regime twenty nine-party alliance was formed to confront the fifteen-party alliance and four-party alliance. ${ }^{3}$ In order to face opposition government formed National Front on August 15, 1985 with five political parties-Janadal, BNP(Shah Aziz),United People's Party, Ganatantric Party, and Muslim League(Siddiqui). ${ }^{4}$

\subsection{Union Parishad Election and Opposition}

For creating support base in rural areas for the regime on July 8, 1983 CMLA Ershad announced local government bodies polls from December 27, 1983. ${ }^{5}$ But seven-party and fifteen-party alliances demanded parliamentary polls first. They did not want to give the regime any chance to create any support base in the grass-root level by allowing local bodies polls first. On October 21, 1983 fifteen-party alliance said that local government polls before parliamentary election was unconstitutional. ${ }^{6}$ Refuting that 18 -point Secretary General Mr. Mahbubur Rahman said that holding local government polls prior to Jatiya Sangsad polls was not unconstitutional. Democracy must come from grass root level and President would be at the top. ${ }^{7}$

Defying the demand of the opposition CMLA H.M. Ershad on October 26, 1983 said that local government polls would be held before parliamentary election. ${ }^{8}$ In protest of government announcement fifteen-party alliance and seven-party alliance observed first hartal on November 1, 1983 across the country to press home their fivepoint demand. ${ }^{9}$ On November 24, 1983 BNP (Sattar) leader and ex-Speaker of Jatiya Sangsad Mirza Golam Hafiz urged the government not to violate constitution by holding local government election prior to Jatiya Sangsad polls. ${ }^{10}$ In reply to statements of opposition leaders Secretary General of 18-point Mr. Mahbubur Rahman said that there was no provision in the constitution which would be violated if local polls was held first. ${ }^{11}$ Defying opposition demand government arranged Union Parishad polls on December 27, 1983 amid Martial Law. ${ }^{2}$

\subsection{Upazilla Parishad Election and Opposition}

In order to create power base in the second tire of local government body government fixed March 24, 1984 for Upazilla polls. In protest fifteen-party alliance and four-party alliance observed hartal on March 1, $1984 .{ }^{13}$ Hasina and Khaleda Zia were kept in house arrest on the hartal day and as a result of violent protest and clashes between police and hartal observer one person was killed. ${ }^{14}$ On March 14, 1984 Khaleda Zia called for the government to put off Upazilla polls scheduled on March 24, 1984. ${ }^{15}$ On March 16, 1984 Khaleda Zia warned the government officials not to conduct Upazilla polls. ${ }^{16}$ Not only that to foil the election fifteen-party alliance and four-party alliance called hartal on election date that is March $24 .{ }^{17}$ In order to create pressure upon the government fifteen-party alliance and four-party alliance observed "Anti- repression Day" on March 18, 1984 and asked the government to cancel Upazilla polls. ${ }^{18}$ Since opposition declared March 24, 1984 as "Resistant Day" the government was forced to shift the election date from March 24, 1984 to May 27, 1984. ${ }^{19}$ But government failed to arrange polls on that date.

On April 9, 1985 CMLA declared that Upazilla Parishad election would be held on and from May 16-20, $1985 .^{20}$ For maintaining and arresting law and order government imposed curfew at Dhaka before the start of Upazilla polls and Khaleda Zia and Sheikh Hasina were kept in house arrest. ${ }^{21}$ Under curfew Upazilla Parishad

Ibid, December 12, 1983, the Sanbad, December 12, 1983

Ibid, March 24, 1984, the Banglar Bani, March 24, 1984

Ibid, March 31, 1984, the Ittefaq, March 31, 1984

Ibid, August 16, 1985, the Ittefaq, August 16, 1984

Ibid, July 9, 1983, the Banglar Bani, July 9, 1983

Ibid, October 22, 1983, the Sanbad, October 22, 1983

Ibid

Ibid, October 27, 1983, the Ittefaq, October 27, 1983

Ibid, November 2, 1983, the Sanbad, November 2, 1983

Ibid, November 25, 1983, the Ittefaq, November 25, 1983

Ibid

Ibid, December 28, 1983, the Ittefaq, December 28, 1983

Ibid, March 2, 1984, the Ittefaq, March 2, 1984

Ibid

Ibid, March 15, 1984, the Sanbad, March 15, 1984

Ibid, March 17, 1984, the Sanbad, March 17, 1984

Ibid

Ibid, March 19, 1984, the Ittefaq, March 19, 1984

Ibid

Ibid, April 10, 1985, the Banglar Bani, April 10, 1985

Ibid, May 16, 1985, the Sangram, May 16, 1985 
election was held on and from May 16 to 20, 1985 despite the opposition of fifteen-party alliance and Jamaat-eIslami and four-party alliance. After the polls Khaleda Zia and Sheikh Hasina were freed on May 25, $1985 .{ }^{1}$

\subsection{Political Dialogue with Opposition}

Dialogue helps in resolving any sort of crisis, enmity or conflict between rival groups or parties. In politics dialogue is used to avoid confrontational politics between government and opposition. Commander in Chief of Armed Forces HM Ershad took over state power in a bloodless coup on March 24, 1982. Within one year from military takeover political parties formed political alliances against military regime of Ershad and asked the government for meeting their several demands including holding election under civilian rule. These alliances viz., AL led fifteen-party alliance and BNP led seven-party alliance had thrown stiff challenge to the military regime of Ershad. With the aim of meeting their demands Ershad government called for several dialogues with political parties. Through these dialogues regime had succeeded in strengthening her political goal. After each dialogue the regime had managed to create mistrust among political parties and to break the bond among the members of political alliances.

\subsubsection{First Dialogue Offer}

In the face of stiff opposition Ershad shun active process of infiltration in politics and adopted passive mechanism of injecting regime's political desire. On February 18, 1983 he invited the politicians to participate in political dialogue to be held in March $1983 .{ }^{2}$ But interesting thing was that most of the political leaders were in jail or absconding in fear of police arrest. In order to make the dialogue fruitful there required players to start with. And to ensure the participation of players government released 27 political leaders from jail on March 1, 1983. Among the released politicians Sheikh Hasina, Sahara Khatun, Matia Chowdhury, Rashed Khan Menon, Dr. Kamal Hossain, Tofael Ahmed, Abdus Samad Azad, Abdul Mannan, etc. were prominent. ${ }^{3}$ The interesting thing was that most of these released leaders belonged to Awami League. It may be recalled Zia by introducing multi-party politics paved the way for resurgence of AL from September, 1976 to till his death on May 30, 1981. ${ }^{4}$ But Ershad reestablished AL as a strong political force against BNP. Ershad said that he had reestablished $\mathrm{AL}(\mathrm{H}) .^{5}$

As a result of dialogue on November 15, 1983 five members from BNP (Sattar) joined 18-point programme. They were Mr. Abdul Matin Chowdhury, M.A. Hye, Mr. Golam Murtuza, Delwar Rahman and Khandakar Siraj. ${ }^{6}$ On November 19, 1983 Mr. Shamsul Huda president of BNP (Huda), Shah Moazzem Hossain president of Democratic League, and Mr. Mizanur Rahman Chowdhury president of Awami League (Mizan) joined the 18-point programme. ${ }^{7}$ On November 20, 1983 Chairman of NAP (Naser) Abu Nasser Khan and Secretary of NAP (Nasser) Abdus Sobhan agreed with the ML regime. ${ }^{8}$ Relying on these grafted and disgruntled political leaders CMLA H.M. Ershad on November 21, 1983 announced that national party would be formed very soon. ${ }^{9}$

\subsubsection{Second Dialogue Offer}

On January 2, 1984 President Ershad second time invited politicians for political dialogue to be held on January 7, 1984. ${ }^{10}$ For creating congenial atmosphere government withdrew curfew on January 3, 1984 and removed ban on indoor politics on January $7,1984 .{ }^{11}$ After this offer leaders of 40 political parties attended the dialogue with the CMLA President Ershad on January 7, 1984. ${ }^{12}$ On January 23, 1984 BNP (Dulu) headed by Mr. Khaliquzzaman Khan the president of BNP (Dulu) and NAP (Nuru) headed by Nurur Rahman supported 18point programme. ${ }^{13}$ Later on BNP (Dulu) melted away in ML regime. For the purpose of defecting other BNP leaders President Ershad on January 27, 1984 pledged to fulfill Zia's dream. ${ }^{14}$

After the second dialogue President Ershad had succeeded to break the bond of seven-party alliance. NAP (Nuru), Krishak Sramik Party and Jatiya League broke away from seven-party alliance and merged with Royal Party front on January 28, 1984. ${ }^{15}$ With the backing of ML regime on January 28, 1984 eleven-party alliance

Ibid, May 26, 1985, the Sangram, May 26, 1985

Ibid, February 19, 1983

Ibid, March 2, 1983

Bahar Abid, An Illustrated History of Bangabandhu and Bangladesh, London, 1997, pp.250-265, and see chapter 3.1.6.3

Ahmed Moudud. Democracy and the Challenge of Development: A Study of Politics and Military Intervention in Bangladesh. Pub1995 Dhaka. PP-316-317

The Bangladesh Observer, November 16, 1983

Ibid, November 20, 1983, the Ittefaq, November, 20, 1983.

Ibid, November 21, 1983, the Ittefaq, November, 21, 1983.

Ibid November 22 1983, the New Nation, November, 22, 1983.

Ibid, January 3, 1984, the New Nation, January 3, 1984

Ibid, January 4 and 8, 1984, The Sangram, January 4 and 8, 1984

Ibid.

Ibid, January 24, 1984, the Ittefaq, January 24, 1984.

Ibid, January 28, 1984, the Banglar Bani, January 28, 1984

Ibid, January 29, 1984, the Sanbad, January 29, 1984 
named Jatiya Jote was formed with Ataur Rahman Khan as its Chairman. ${ }^{1}$ As result of defection in BNP led seven-party alliance after January 28, 1984 this alliance turned into four-party alliance.

This Jatiya Jote on January 29, 1984 demanded the government to remove ban on politics. ${ }^{2}$ However, fifteen-party alliance led by Hasina and four-party alliance led by Khaleda did not join the dialogue. On February 8, 1984 President Ershad again urged fifteen-party alliance and four-party alliance to sit in dialogue. ${ }^{3}$

\subsubsection{Third Dialogue Offer}

On March 18, 1984 Ershad government convened a roundtable conference of all political parties including fifteen-party alliance and four-party alliance. ${ }^{4}$ In response to the offer of dialogue fifteen-party alliance and fourparty alliance asked the regime to create congenial atmosphere for talk. ${ }^{5}$ As a process of creating favourable atmosphere government on March 27, 1984 withdrew ban on politics. ${ }^{6}$ But fifteen-party alliance, four-party alliance and Jamaat-e- Islam stuck to their five-point demand for withdrawal of martial law, election under neutral government etc. ${ }^{7}$

Khaleda Zia leader of four-party alliance on March 28, 1984 declared that her party would not participate in the polls under ML. ${ }^{8}$ Ershad on March 29, 1984 said there would be no caretaker government. ML would stay till the Jatiya Sangsad was summoned. ${ }^{9}$ However Khaleda Zia on April 1, 1984 asked the government to fulfill three conditions before the dialogue. The conditions were:- ${ }^{10}$

1) Dialogue must be based on five-point demand.

2) A neutral government must conduct the election.

3) The parliamentary polls would be held on May 27, 1984 .

Fifteen-party alliance said five-point would be the basis of dialogue and Jamaat-e-Islam stick to election under non-party caretaker government. ${ }^{11}$

Since preconditions were not met Khaleda Zia did not sit with government for dialogue. Fifteen-party alliance and Jamaat sat with the government on April 11 and 10, 1984 respectively. AL asked the President to withdraw ML. ${ }^{12}$ During the dialogue Jamaat requested the president not to stand for polls. ${ }^{13}$

However on April 12, 1984 Khaleda Zia met with President Ershad and exchanged views regarding the implementation of five-point demand of four-party alliance. Zia asked the government to restore fundamental rights before election. ${ }^{14}$ Second round of dialogue was held with fifteen-party and Jamaat on April 13 and 14, 1984. ${ }^{15}$ Fifteen-party and four-party demanded withdrawal of ML first. ${ }^{16}$ Four-party held dialogue on April 19, 1984 and demanded execution of five-point demand. ${ }^{17}$ On April 20, 1984 H.M. Ershad accepted that parliamentary polls would be held before other polls. ${ }^{18}$ On April 29, 1984 Ershad deviating from his earlier declaration said election would be held under suspended constitution and under ML. ${ }^{19}$ As a result dialogue ended in smoke.

\subsubsection{Fourth Dialogue Offer}

On October 3, 1984 Chief Election Commissioner announced December 8, 1984 for parliamentary polls. ${ }^{20}$ However government did not say anything regarding lifting of ML. The opposition refused election under ML. In order to make the opposition agree to stand in polls President offered a package deal on October 9, 1984 and the offer was to take it or leave it.

The package deal was $^{21}$

I. Partial withdrawal of ML.

II. Partial restoration of fundamental rights.

III. Limited use of mike and holding of roadside meeting.

\section{Ibid.}

Ibid.

Ibid, February 9, 1984, Ittefaq, February 9, 1984

Ibid, March 19, 1984, Ittefaq, March 19, 1984

Ibid, March 25, 1984, Ittefaq, March 25, 1984

Ibid, March 28, 1984, Ittefaq, March 28, 1984

Ibid, March 29, 1984, Ittefaq, March 29, 1984

Ibid

Ibid, March 30, 1984, the Sangram, March 30, 1984

Ibid, April 2, 1984, the Sangram, April 2, 1984

Ibid, April 2 and 3, 1984, the Ittefaq, April 2 and 3, 1984

Ibid, April 12, 1984, the Ittefaq, April 12, 1984

Ibid, April 11, 1984 the Ittefaq, April 11, 1984

Ibid, April 13,1984, the Sangram, April 13, 1984

Ibid, April 14 and 15, 1984, the Banglar Bani, April 14 and 15, 1984

Ibid, April 19, 1984, the Sanbad, April 19, 1984

Ibid, April 20, 1984, the Ittefaq, April 20, 1984

Ibid, April 21,1984, the Ittefaq, April 21, 1984

Ibid, April 30, 1984, the Sanbad, April 30, 1984

Ibid, October 4, 1984, the Sanbad, October 4, 1984

Ibid, October 10, 1984, the Sanbad, October 10, 1984 
IV. Ensure congenial atmosphere for holding an impartial election.

In protest of that offer opposition called hartal on October $15,1984 .{ }^{1}$ Government barred publication of news regarding hartal on that day. ${ }^{2}$ On October 18, 1984 the opposition declared to resist the polls. ${ }^{3}$ Consequently government postponed the presidential polls scheduled on December 8, 1984. ${ }^{4}$ Opposition observed countrywide hartal on December 8, 1984. ${ }^{5}$ On the eve of December 16, 1984 President Ershad fixed new date for parliamentary polls in mid April, 1985. He also declared that fundamental rights and partial writ jurisdiction would be restored on January $1,1985 .^{6}$

\subsection{Hartal "Weapon of Materializing Opposition Goal"}

Although Ershad took over power to improve economic condition, arrest law and order, maintain administrative and judicial sanctity but he failed in this respect due to hartals. The fifteen-party alliance and four-party alliance often used hartal as the only mechanism left to materialize their demands against the ML regime. Being frustrated of hartal ML regime in order to arrest and paralise the anti-regime activities of the fifteen-party alliance and four-party alliance on December 20, 1984 prohibited hartal by MLO. ${ }^{7}$ In protest of this ML Order fifteen-party alliance and seven-party alliance observed hartal on December $22,1984 .^{8}$

\subsection{Referendum}

In the face of acute opposition government shifted presidential election date from December 8, 1984 to April 16, 1985. ${ }^{9}$ In spite of that opposition declined to participate in polls under Ershad. ${ }^{10}$ Ershad said his 18 -point became Magna Carta ${ }^{11}$ and government would hold polls. ${ }^{12}$ Being frustrated of government "go alone" policy four-party alliance declared to resist presidential polls scheduled on April 16, 1985. ${ }^{13}$ Consequently government put off presidential polls. ${ }^{14}$ After failure in holding polls, Ershad on February 27, 1985 announced that government would hold referendum. ${ }^{15}$ King party Janata Front demanded referendum on 18-point programme. ${ }^{16}$ But fourparty alliance declared that they would resist referendum if arranged. ${ }^{17}$ However on March 1, 1985 defying opposition threat President Ershad announced that referendum would be held on March 21, 1985 on his 18-point programme. He also banned all political activities and revived ML courts. Not only that in order to weaken the opposition strength all educational institutions particularly universities were closed sine-die. ${ }^{18}$ At the same time President expressing his faith on armed forces said, "Armed Forces will control chaos." 19 Accordingly on March 21, 1985 referendum took place on 18-point programme under tight security and the regime got 94.14 percent yes votes. $^{20}$

\subsection{Jatiya Party as Ultimate Political Platform of Ershad}

As a last resort in order to reach the people government formed Jatiya Dal on January 1, 1986 by merging Janadal, BNP (Shah Aziz), Muslim League, United People's Party, and Ganatantric Party with Dr. M.A. Matin as Secretary General. However the post of party Chairman remained vacant. ${ }^{21}$ President H.M. Ershad used it as a platform to motivate the audiences towards his rule. Very often he was invited as Chief Guest in the party gatherings and delivered his good speeches. On March 2, 1986 Ershad said, "I have people's verdict." Ignoring opposition's demand government declared April 26, 1986 as the date for parliamentary polls and at the same time he urged the opposition to participate in polls. ${ }^{22}$

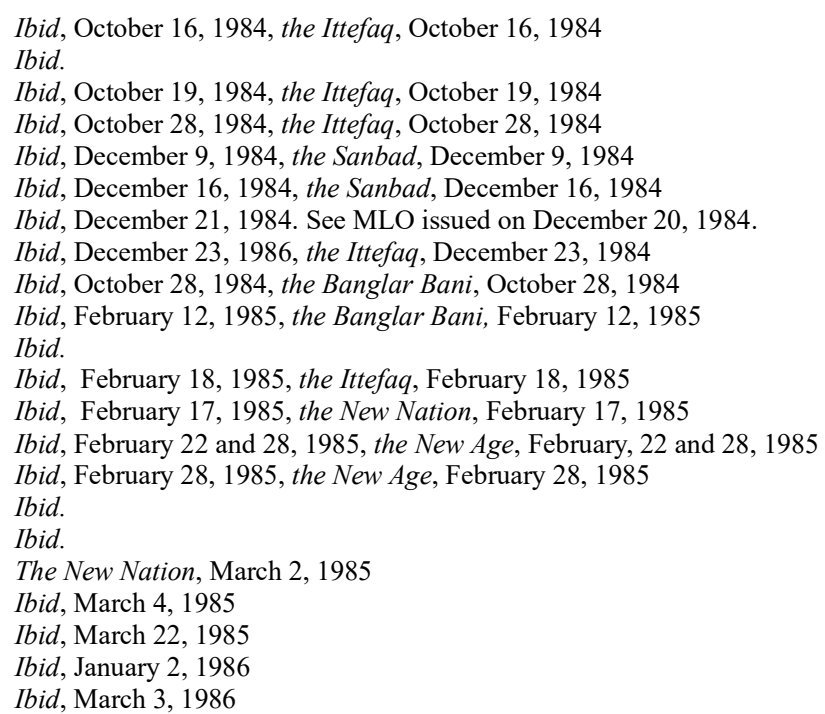




\subsection{Popularity of Alliance Leaders and Tactics of the Regime}

In order to ensure the defeat of Ershad regime Awami League and BNP decided to nominate their respective party Chairman Sheikh Hasina and Khaleda Zia for polls from 150 constituencies each. At this the government became fearful of losing all seats of the parliament to the opposition. In order to stop such action of the opposition on March 15, 1986 government brought change in the RPO of 1972 that no candidate can stand for election from more than five seats at a time. ${ }^{1}$ On March 18, 1986 Awami League and BNP filed a Writ petition challenging this change to the Representation of People's Order 1972. But the Supreme Court rejected that petition saying that under ML CMLA has supreme power to do any change. ${ }^{2}$

\subsection{Secret Dialogue and Collapse in Opposition}

In spite of all steps and political propaganda government failed to move the rigid stand of fifteen-party alliance, four-party alliance and Jamaat-e-Islam against presidential and parliament elections under his reign. CMLA Ershad appointed four Ministers to make liaison with these opposition parties on January $30,1986 .{ }^{3}$ As a result of secret dialogue all of a sudden on March 21, 1986 Awami League decided to participate in the election under ML surprising its alliance as well as four-party alliance. ${ }^{4}$ As a result fifteen-party alliance was reduced to eightparty. ${ }^{5}$ Bangladesh Workers Party, JSD (Siraj), CPB, NAP (Unity), Muslim League, JSD (Rab), BAKSAL (See 3.1.6.3), NAP (M), Jamaat-e-Islam also agreed to take part in polls under government's plan. ${ }^{6}$

\subsection{Election under Martial Law}

In order to save the election from failure CMLA made MLR-V prohibiting anti-election propaganda and activities on May 3, $1986 .{ }^{7}$ Khaleda Zia was made house arrest under this new MLR on May 4, $1986 .{ }^{8}$

At last Second Parliamentary election was held on May 7, 1986. In the election rampant vote rigging was common according to UK observers. AL termed it as "polls piracy." Jamaat called the polls as farce. ${ }^{9}$ British MPs said vote rigging was common in the polls. ${ }^{10}$ Eight-party alliance led by AL observed hartal on May 14, 1986 in protest of rampant rigging in election. ${ }^{11}$ In the election Jatiya Party got 152 seats, $\mathrm{Al}(\mathrm{H})$ bagged 75 seats, Jamaat received 10 seats, CPB obtained 5 seats, NAP(Unity) 5 seats, Muslim League 4, JSD(Rab) 4, JSD(Siraj) 3, BAKSAL 3, Workers Party 3, NAP(M) 2, Independent candidates 33 seats. $^{12}$ It is necessary to mention that here BAKSAL was a political party not the National Party which President Mujibur Rahman had set up on February 25, 1975. Abdur Razzak was the president of BAKSAL. This party was formed and registered in 1976. After Jatiya Sangsad polls presidential polls was held on October 16, 1986. CMLA H.M. Ershad was the candidate of the Jatiya Party. Twelve candidates participated in the race. Jatiya Party candidate CMLA Ershad became victorious bagging around $70 \%$ percent votes. His nearest contender Hafezi Huzur got $25 \%$ votes. $^{13}$

1.19 Constitutional Sanction of all Businesses Carried Out by Military Government of Ershad: The military regime under the leadership of Gen. H.M.Ershad brought extra-ordinary reforms in administrative set up such as in local government bodies, judiciary, infrastructural sectors, agricultural field, and healthcare, etc through Martial Law Regulations. But these had no legality as that of her taking over of state power. After becoming victorious in Presidential polls on October16, 1986 CMLA President Ershad said Jatiya Party was strong enough to pass Indemnity Bill. ${ }^{14}$ With the object of giving legal effect to these actions Jatiya Party, the spokes person of military regime, brought seventh amendment to the Constitution of Bangladesh. This amendment inserted the following provisions into the Constitution. :-

\subsubsection{Increase of Retirement Age of Supreme Court Judges}

Government, in order to reduce the suffering of litigants from remote areas of the country, decentralized the highest court and set up six permanent benches of the High Court Division outside Dhaka. As a result of which number of judges of the High Court fall short. Not only that these new Benches required experienced judges to earn the confidence of the people. In a short period of time appointment of new judges were not possible because of the hostile opposition of the lawyers. To ensure the participation of experienced judges the government

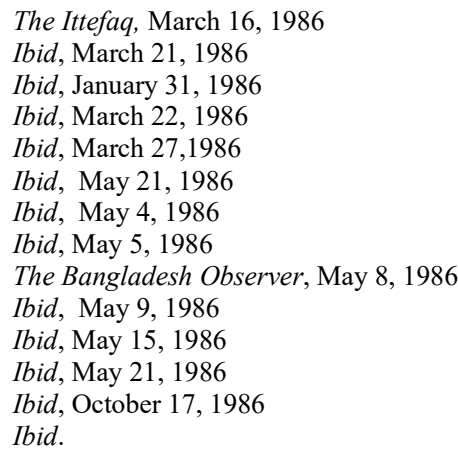


increased the retiring age of the Supreme Court judges from 62 to $65 .{ }^{1}$

\subsubsection{Amendment of First Schedule}

The State Acquisition and Tenancy Act, 1950 stood in the first Schedule of the Constitution. President Ershad promulgated the Agricultural Labour (Minimum Wages) Ordinance 1983 and the Land Reform Ordinance and Land Reforms Rule, 1984 to make law more common people oriented. ${ }^{2}$

The Agricultural Labour (Minimum Wages) Ordinance 1983 fixed the minimum wage for farm labourer at three and half seers of rice or its equivalent price.

The main features of the Land Reform Ordinance and Land Reforms Rule were-

(1) Person who has 60 bighas of land already in his ownership shall not own further land. In excess of that ceiling will be vested with the government without giving any compensation to the owner.

However compensation will be given at the rate of 20 percent of market value of the land if such land is owned by inheritance.

(2) Without agreement none shall give his/her land to other for cultivation. The period of share-cropping agreement shall be at least five years. In the agreement there shall be the signature of three parties, viz. owner, share-cropper and the proper authority. This Ordinance did not define proper authority. However it said that government by gazette notification from time to time would specify the name and designation of such proper authority.

The share-cropper will get two-thirds of the produce and one-thirds will go to the owner.

Without the prior approval of the authority such agreement will not be unilaterally revoked by the owner.

The government also formed Board of Land Administration to hear appeal against the decision of Divisional Commissioner and Deputy Commissioner.

All these provisions were inserted in the State Acquisition and Tenancy Act, 1950.

These provisions protected interests of rural workers and share-croppers. But government could not implement the maximum ceiling of 60 bighas of land. The provision of share cropper was partly implemented with respect to distributing produce of land in winter and summer seasons. The provision regarding written agreement for share-cropper has not yet been seen implemented.

\subsubsection{Amendment of Fourth Schedule.}

For giving immunities to all the acts, deeds, amendments, appointments, dismissals by the martial law regime done from March 24, 1982 to November 10, 1986 in fourth schedule of the constitution after paragraph 18 new paragraph 19 was added in the constitution. The provisions of the paragraph are as follows- ${ }^{3}$

a) The proclamation of March 24, 1982 and all other proclamations, proclamation orders, Chief Martial Law Administrators orders, Martial Law Regulations, Martial Law orders, Martial Law instructions, Ordinances, and all other laws made during the period between March 24, 1984 and the date of commencement of Constitution (Seventh Amendment) Act, 1986 (both days inclusive) hereinafter in this paragraph referred to as the said period are hereby ratified and confirmed, and declared to have been validly made, and shall not be called in question in or before any court, tribunal or authority on any ground whatsoever.

b) No suit, proclamation or other legal proceeding shall lie in any court or tribunal against any person or authority for or on account of or in respect of any order made, act or thing done or action or proceedings taken during this period.

c) All appointments made during this period between March 24, 1982 to November 10, 1986 (both days inclusive) shall be valid and shall remain valid after the passage of the Constitution (Seventh Amendment) Act, 1986.

d) All Ordinances and other laws in force immediately before the proclamation of $24^{\text {th }}$ March, 1982 shall operate subject to the amendments made during the period from March 24, 1982 and November 10, 1986 (both days inclusive). ${ }^{4}$

These provisions legalized all the actions, orders, laws, regulations, deeds of Ershad government starting from March 24, 1982 to November 10, 1986 including illegal taking over of state power by him.

With the passage of the Constitution (Seventh Amendment) Act, 1986 Constitution was restored and Martial Law was withdrawn. ${ }^{5}$ In protest of the passage of the Amendment Act nationwide hartal was observed by BNP led four-party alliance, Jamaat-e-Islam and five-party alliance on November $10 .{ }^{6}$ Although Jamaat-eIslami and five-party alliance led by Rashed Khan Menon and Hasanul Huq participated in the third parliamentary election under ML but they, according to them, did not get their expected result because of

Ibid, and see also chapters 2.4.15, 2.9.3 and 3.1.9.3

The Bangladesh Observer, September, 18, 1984, and see also chapters 3.1.4 and 3.1.13.1

See Act No. I of 1986 published in official gazette on November 11, 1986

See chapters 2.4.32, 2.6.1, 2.7.22, 2.9.6, 3.1.13.3 and 3.4.15

The Bangladesh Observer, November 11, 1986

Ibid 
rampant rigging. They felt cheated by the ML government. Thus they did not recognize third parliament. As a sign of dismay they joined main opposition BNP against the rule of ML government. BNP chairperson Khaleda Zia alleged that all illegal acts were legalized by Seventh Amendment Act. ${ }^{1}$

In Siddique Ahmed vs Bangladesh the Supreme Court nullified the seventh amendment on May 15, 2011. But interestingly it upheld the changes made in the constitution regarding the increase of retirement age of the judges of the Supreme Court and incorporation of land law reforms in the East Bengal State Acquisition and Tenancy Act, 1950 in first schedule of the constitution. Not only that, it kept the operation of other laws such as Income Tax Ordinance, 1984, Family Court Ordinance, 1985 etc intact. ${ }^{2}$

The Constitution seventh amendment bill was introduced and passed within five hours on November 10, 1986 giving indemnity to all actions of the Ershad government from March 24, 1982 to November 10, 1986. ${ }^{3}$ The Appellate Division on May 15, 2011 negated the seventh amendment. But it did not declared the political policy of the regime such as promotion of subdivisions to districts, economic austerity policy, corruption drive, development of transport sectors such as collection of fund for Jamuna Bridge, development of roads and highways, holding of local government polls, formation of JP, etc illegal.

\section{Conclusion}

Though Ershad's power grapping was illegal yet he made extra ordinary efforts to bring back democratic culture of his choice in Bangladesh. In doing so the regime tried a lot by initiating different programs such as drive against corruption, cleanliness, austerity drive, to depict her positive image before the people. Decentralization of judiciary was the outstanding deed of the military regime, no doubt. These programs attracted the people as a whole but declaration of 18-point programs created negative impact upon the politically conscious people of the country. With the aim of countering the political aspiration of Ershad political parties formed alliances for starting political movement for the cause of establishing democratic rule. The regime with the object of weakening opposition movement and creating political support base periodically arranged local elections. It traded top leaders of main opposition parties and formed Jatiya Party(king party) with these grafted politicians. The regime through the application of different tricks and tactics succeeded to hold third parliamentary polls in the participation of all political parties except BNP and passed presidential vote but could not get legitimacy, for these polls were always tainted by massive vote rigging. However, the regime of Ershad legalised all actions and deeds- right or wrong by the passage of seventh amendment. Ershad could not manage BNP led by Begum Khaleda Zia. He remained unsettle in power in fear of uncompromising stand of Khaleda Zia. 